\title{
IDENTIFYING STUDENTS' LEARNING STYLES IN UNDERSTANDING EXTERNALITIES
}

\author{
Aw Yang Huey ${ }^{1}$ \\ Faculty of Business Management, Universiti Teknologi MARA, \\ Perak Branch, Seri Iskandar Campus, Seri Iskandar, 32610 Perak, Malaysia. \\ (Email: awyan804@uitm.edu.my) \\ Teh Boon Teck ${ }^{2}$ \\ Faculty of Arts and Social Science, Universiti Tunku Abdul Rahman, \\ Kampar Campus, Bandar Barat, 31900 Kampar, Perak, Malaysia. \\ (Email: tehbt@utar.edu.my) \\ Kursimah Bt. Harun ${ }^{3}$ \\ Faculty of Business Management, Universiti Teknologi MARA, \\ Perak Branch, Seri Iskandar Campus, Seri Iskandar, 32610 Perak, Malaysia. \\ (Email: kursi044@uitm.edu.my) \\ Mohd. Fareh Bin Majid ${ }^{4}$ \\ Faculty of Architecture, Planning and Surveying, Universiti Teknologi MARA, \\ Perak Branch, Seri Iskandar Campus, Seri Iskandar, 32610 Perak, Malaysia. \\ (Email: mohd898@uitm.edu.my)
}

Received date:01-09-2018

Revised date: 17-10-2018

Accepted date: 05-08-2019

Published date: 12-09-2019

To cite this document: Aw, Y. H., Teh, B. T., Harun, K., \& Majid, M. F. (2019). Identifying Students' Learning Styles in Understanding Externalities. International Journal of Education, Psychology and Counseling, 4 (32), 01-11.

DOI: $10.35631 /$ IJEPC.432001

\begin{abstract}
This survey was conducted to determine which learning styles will improve students' level of understanding externalities. A cross-sectional study was conducted among 178 Business Economics students, who were taking the Public Finance course at an institute of higher education in Perak. A set of formulated questionnaires was distributed to all the participating students. Only 146 completed questionnaires were returned and the students' chosen learning styles in understanding externalities, net gains in well-being, and internalizing negative externalities were analyzed using SPSS software. Findings from the collected data revealed that students learned externalities better by using presentation software in the classroom and by applying mathematical models. The R-squared value indicated that $62.4 \%$ of the good grades obtained by the students can be explained by the application of mathematical tools and by integrating technology into the classroom. Mathematics is a core skill that provides access to externalities. Meanwhile, learning about externalities by watching business talks had helped the students to experience real-world situations. However, the survey results had also revealed that previous knowledge in taxation did not have a significant effect on students'
\end{abstract}


performance in internalizing negative externalities. The application of diagrams in the course of study also failed to have any significant effect on the students' test grades.

Keywords: Public Finance, Mathematical Models, Externalities

\section{Introduction}

An externality stems from the production or consumption of a good or service, resulting in a cost or benefit to an unrelated third party. Equilibrium is the ideal balance between buyers' benefits and producers' costs which result in the optimal level of production. However, externalities could affect this equilibrium and lead to market failure because a product's equilibrium price does not accurately reflect the true costs and benefits of that product. Externalities are costs or benefits that are the result of activities generated by one party, which affect another party, who did not choose to incur the costs or benefits in the economy. For example, when various industries pollute a river and they fail to account for the costs of the pollution, but the society has to pay for it, this is known as negative externality. In this case, the industries would have lower marginal costs compared to their marginal benefits ( $M B \neq M C)$. This condition would result in a deadweight loss or excess burden, as shown in the shaded area in Figure 1. The analysis of market failure and possible ways of correction are important issues in public finance. Therefore, citizens should learn about public finance to better understand market failure and the need for government intervention in the economy to develop a better society.

Figure 1: Deadweight Loss

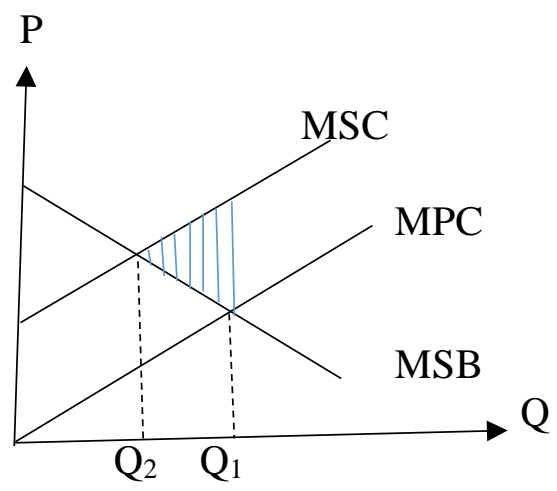

In December of 2017, Reuters reported that China planned to develop a system that would make polluters pay for the damages they have done to the environment in the attempt to correct market failures from negative externalities. This system will be successful only if the citizens are equipped with the knowledge of internalising externalities. To get the prices right, they should be taught all possible means of correcting externalities, which include how to change a company's private costs or benefits and make them equal to the company's social costs or benefits. Only then will the citizens understand the policies introduced by their government to address market failures. According to Noah Smith from Bloomberg Opinion, it is difficult to explain market failures. The demand to demonstrate a market failure is not fair because it puts too much burden of proof on advocates of intervention. In addition, Smith opined that government intervention in the economy is often successful in internalising externalities, even if the citizens do not understand why it works. 
Another case to ponder over is the use of out-dated devices. The June 3 to June 10, 2019 issue of TIME magazine reported that approximately 6 million $\mathrm{lb}$. of discarded electronics are processed monthly at the Electronic Recyclers International's (ERI) Fresno plant, but not all are recycled. Some might end up in landfills, which would generate an environmental cost as e-waste can contain harmful materials, such as mercury. The Extended Producer Responsibility (EPR) laws were passed by lawmakers in parts of Europe and Canada, and in some U.S. states, which require manufacturers to establish and fund systems to recycle or collect obsolete products. However, even when e-waste rules exist, consumers should also be trained on how to properly handle their old devices. Once they understand externalities, they will understand the environmental impacts of it. Subsequently, they will not be put off by the prospect of bringing old electronics to a store that might charge them for disposal services. As for the manufacturers, they should try to make electronic products last as long as possible to slow the pace of obsolescence. Figure 1 shows the deadweight loss as the shaded area and MSC > MSB can be seen at Q1. The quantity from Q1 to Q2 must be reduced so that MSC $=$ MSB to maximise social surplus, which will benefit the society.

Figure 2 shows the different learning styles available, such as visualising learning, auditory learning, physical learning, and social learning. Visual learners prefer learning using graphs, diagrams, and symbols over words, while auditory learners prefer listening, such as to a lecture or discussion. Physical or kinaesthetic learners prefer to learn via experiences and they excel in on-the-job training, while social learners prefer learning in groups or classes. There are also logical, verbal, and solitary learning styles. Logical or mathematical learners use logic and reasoning in their studies, while verbal or linguistic learners prefer using words. As for solitary learners, they prefer to work alone and use the self-study style.

Figure 2: Learning Styles

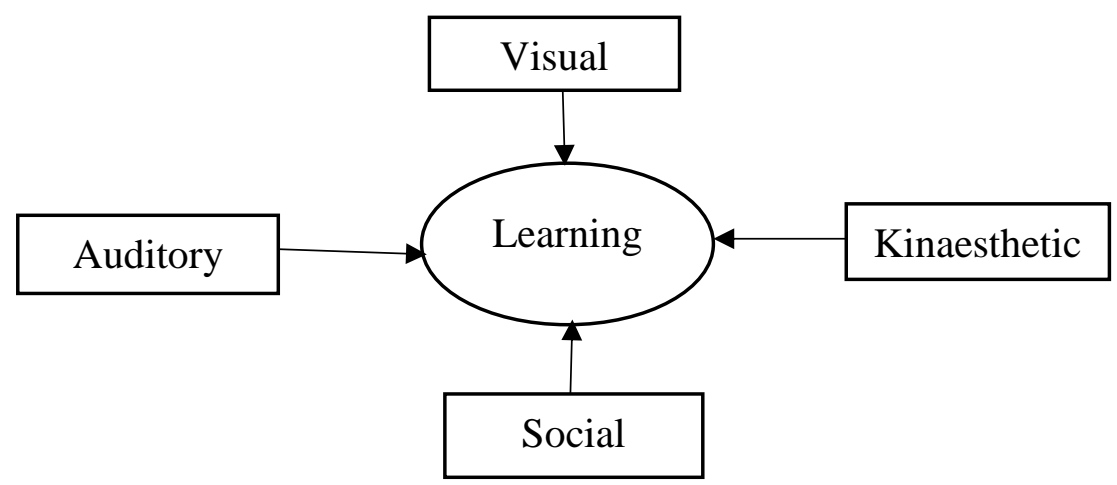

Thus, it can be said that there are many ways to learn externalities. Some students are comfortable learning externalities in Public Finance by reading textbooks and some might enjoy studying in a group, while others learn best through graphical representations. Other students might also prefer the application of information to real world situations. In other words, each student prefers different learning styles and they might use different styles in different situations to help them absorb and understand information. Since not all students learn the same way, there is a need to identify their learning styles that will enable them to reach their full potential and to reduce stress in the classroom. Therefore, different teaching and learning styles, in 
addition to traditional lectures, should be incorporated to enhance students' understanding in this course.

\section{Literature Review}

The body of literature reviewed in this section aims to highlight previous researches that examined students' learning preferences, and the application of diagrams, mathematical tools, and technology in the classroom.

\section{Students' Preferences in Learning}

Bada and Okan (2000) studied students' language learning preferences in Cukurova University, Turkey. They interviewed 230 students at the ELT Department, Faculty of Education, who stated their views as to how they prefer to learn English. They also interviewed 23 teachers regarding their awareness of the students' learning preferences. They found that learning preferences are important in the development of learners' autonomy. To avoid resistance when introducing an instructional activity in the classroom, teachers should consider the students' preferences and take into account the various learning methods. Many teachers have acknowledged that learners have different learning preferences. Thus, they should also consult their students before conducting any activities in the classroom. This study has shown that both students and teachers need to work closely together and foster better cooperation in arranging and implementing learning activities to realise effective collaboration and learning outcomes.

\section{Students' Learning Styles}

According to Zainal Arifin (2015), several variables could affect the success of learning a language, especially a second or foreign language, and one of such variables is learning styles. It was stressed that teachers should identify the students' learning styles and work with them. A study was conducted on the different learning styles of 15 ESL students at SMPN 1 Dagangan, Madiun Regency of East Java. These students were classified based on gender and three levels of competencies. Reid's Perceptual Learning Style Preference Questionnaire and interviews were conducted. This study discovered that the students can be categorised as visual, auditory, kinaesthetic, tactile, individual, and group learners. The results revealed some differences in the learning styles used by these students within the three levels of competencies. The results also indicated that there was a small difference between male and female students when using different learning styles. Male students preferred studying alone, while female students preferred learning as a group. The average results, however, showed that both gender chose group learning style as their preference.

By incorporating the Felder-Silverman learning style model, Graf, Kinshuk, and Liu (2008) proposed an automatic approach for identifying the learning styles of students who were learning management systems online. These students' learning styles were automatically identified using their behavioural indications while they were studying online. This method allowed the students to be aware of their learning styles and help teachers to understand why their students were experiencing problems in learning activities. By using a sample of 127 students, the researchers compared the results from this automatic approach with results from students using learning styles questionnaire. This method can also be used to prepare learning materials that take into consideration the different learning styles and make learning easier for each student. 


\section{Application of Mathematical Tools}

Misfeldt, Mariager-Anderson, and Lindenskov (2012) from Aalborg University and Aarhus University investigated the importance of mathematics in learning economy. Their survey was a part of a larger project, which was conducted in an economics programme at a university, to prove the significance of mathematics in learning economics. Their study used the qualitative method to show that mathematical skills can be a predictor of performance of economics students. They presented empirical reasons for including mathematics in economics programmes and discovered different approaches as to how mathematics can be implemented. In one of their investigations, they revealed a teaching method, known as the Synergistic Integration Method by Hudgins (2010), for teaching economics and mathematics to enhance higher thinking order. This method is frequently used in mathematical applications through problem designing and presentation. They concluded that mathematical concepts are life skills that should be incorporated into the classroom to nurture the minds of the students and to articulate their thinking to solve economic problems.

\section{Technology Usage}

Afzal Muhammad Tanveer and Nazia Fardous (2016) applied a mixed method to determine learners' preferred technology usage for their learning engagements in public colleges in the district of Sialkot, Pakistan. Their learning engagements included notes, quizzes, and feedbacks by the teachers. The researchers used questionnaires and face-to-face interviews with 67 randomly selected students as the study sample. The response rate was $100 \%$ since the questionnaires were personally distributed. The researchers assigned numbers in their questionnaires for the students to dictate their preference of technology usage. The results from the questionnaire were supported by the results from the interviews. The students preferred to use Skype and Facebook in their learning engagements. Other social networks, such as WhatsApp, mobile SMS, and Twitter were the least preferred in their learning process. The results also showed that these students have full knowledge of social media usage in the teaching and learning process.

\section{Power Point Presentations}

Fateme Samiei Lari (2014) conducted a study by applying technology in the classroom. A comparison study was conducted on technology usages, such as Power Point presentations using a video projector, as well as on traditional learning methods, such as using textbooks, and on students' learning and motivational levels in secondary schools in Lar, Iran. The purpose of the study was to investigate the effectiveness of these methods and to determine whether students prefer using technological approaches or traditional learning methods in teaching and learning. A group of 56 female students in a secondary school was split into two smaller groups, namely, the experimental and control groups. The researcher taught each group separately. The results from an independent sample t-test indicated that there was a significant difference between the learning means of these two groups. The experimental group had performed better than the control group that used traditional methods. It was concluded that using technological methods for teaching and learning had a significant positive effect on learners' scores.

\section{Drawing Diagrams}

The University of Victoria, Canada posted an article on their website entitled, 'How to study economics'. The article proposed that the best way to learn economic models is by 'playing' with them. The students were encouraged to do exercises, such as working out the problems, drawing pictures, and asking questions. This type of learning was supported by researchers 
from the University of Waterloo. They discovered that drawing pictures is a good strategy to improve memory and makes it easier for a person to remember information (Science Daily, April 21, 2016).

Meanwhile, John D. Hey (2005), a professor of economics and statistics at the University of York, UK, found that accurately drawn graphs let the students see the key results when learning intermediate microeconomics. From his vast personal teaching experiences, he observed that using graphs to illustrate the results, without using the algebra approach, would allow the students to 'see and feel' the economics rather than fear the algebra. Numerous graphs and diagrams will make the lessons livelier and more exciting. This approach could help the students to understand economics better, for example, in explaining the demand theory that involves preferences and indifference curves. He had also demonstrated how to teach intermediate microeconomics by using graphs in the textbook to illustrate the general principles and to let the computing software handle the mathematics. Accurately drawn graphs suit the needs of the students in understanding economics.

\section{Learning Externalities}

According to Seung Mo Choi (2011), an economist at the IMF Institute for Capacity Development and previously an Assistant Professor at the Washington State University, U.S.A., the quantitative features of human capital externalities are not fully understood. His article "How large are learning externalities?" appeared in the International Economic Review, in which he stated that learning externalities remain mostly underestimated, although static externalities are estimated in some studies. His research was supported by the Korean Foundation for Advanced Studies, whereby he calibrated a growth model to estimate learning externalities by using an equilibrium condition that equates private returns on physical capital and human capital. The results suggested that sizable learning externalities exist, even in a conservative setup. Thus, it was concluded that human capital externalities are an important source of economic growth.

\section{Education Externalities}

Both Daniel Munich and George Psacharopoulos (2011) stressed that education externalities is an important issue. They elaborated that it is important to document the benefits of education beyond those recognised by the educated individuals themselves. This is because evidence of such benefits can alter the priorities and approaches used in educational policies. Taking externalities into consideration raises the estimate of the social rate of return to education. An individual may not know all the benefits that he/she could be enjoying in the future with the current education that he/she is receiving. For example, a more educated individual may adopt higher hygiene standards and thus, reduce the spread of diseases to others. This will eventually reduce public spending on treatments, which will subsequently reduce the tax burden imposed on the citizens. The following Table 1 indicates the average values of non-pecuniary indicators in OECD countries based on the level of education. 
Table 1: Indicators of the Average Values of Non-pecuniary Benefits Based on level of Education in OECD Countries (\% of Adults with Particular Educational Attainment)

\begin{tabular}{|l|c|c|c|}
\hline \multicolumn{1}{|c|}{ Indicator } & $\begin{array}{c}\text { Below } \\
\text { upper } \\
\text { secondary }\end{array}$ & $\begin{array}{c}\text { Upper } \\
\text { secondary }\end{array}$ & $\begin{array}{c}\text { Tertiary } \\
\text { level }\end{array}$ \\
\hline In good health & 65 & 79 & 88 \\
\hline Obese & 25 & 19 & 13 \\
\hline Smoker & 36 & 30 & 18 \\
\hline Volunteer & 12 & 18 & 22 \\
\hline Trusts others & 23 & 18 & 29 \\
\hline $\begin{array}{l}\text { Has say in } \\
\text { Government }\end{array}$ & 74 & 79 & 43 \\
\hline $\begin{array}{l}\text { Participates in } \\
\text { elections }\end{array}$ & 58 & 67 & 76 \\
\hline Satisfied with life & & 30 & 87 \\
\hline
\end{tabular}

Source: Based on OECD, Education at a Glance, various years

Table 1 shows that education has positive association with a range of indicators. For example, a more educated individual would decrease the incidence of smoking, thus reducing smokingrelated diseases and benefitting other individuals.

\section{Research Questions \& Objectives}

1. Does the application of mathematical models in the classroom increase students' understanding in externalities?

2. Does using a presentation software, such as Power Point in the classroom, increase students' understanding in externalities?

3. Do drawing diagrams in learning externalities relates to students' performance?

4. Does previous knowledge in taxation help the students in their performance in internalising externalities?

This study focused on a survey among the Business Economics students, consisting of 15 males and 131 females. The main objective was to determine the types of learning styles that could increase students' understanding in externalities by analysing their test scores.

\section{Methodology}

This cross-sectional study was completed in 2017 using simple random sampling among Business Economics students at an institute of higher education in Perak. A set of formulated questionnaires was distributed to 178 Business Economics students and only 146 completed questionnaires were returned. The questionnaire was divided into three sections, namely, demographic data (4 items), application of learning styles (5 items), and topics in public finance (6 items). The Likert scale was used, ranging from 1 (Strongly Disagree) to 5 (Strongly Agree). The reliability test was examined and the value for Cronbach's alpha based on this study was 0.636, which indicated a fair reliability. The collected data were analysed using SPSS Statistics. 


\section{Results and Discussion}

The following Table 2 shows the results of collinearity statistics.

Table 2: Collinearity Statistics

\begin{tabular}{ll}
\hline IV & VIF \\
\hline Maths & 1.951 \\
Presentation Software & 1.830 \\
Drawing Diagrams & 1.018 \\
Previous knowledge & 1.088 \\
\hline
\end{tabular}

Based on the table, all independent variables were free from any multi-collinearity problems as their VIF values were less than 5. The VIF values for Maths, Presentation Software, Drawing Diagrams, and Previous Knowledge were 1.951, 1.830, 1.018, and 1.088, respectively.

\section{Multiple Regression Analysis}

The multiple regression analysis was employed because it provides the most accurate interpretation of the independent variables. According to Sekaran and Bougie (2013), multiple regression analysis is a statistical technique that simultaneously develops a mathematical relationship between two or more independent variables and an interval-scaled dependent variable.

Table 3: Coefficients of the Study

\begin{tabular}{|c|c|c|c|c|c|}
\hline Variable & $\begin{array}{c}\text { Unstandardised } \\
\text { B }\end{array}$ & $\begin{array}{c}\text { Unstandardised } \\
\text { Std. Error }\end{array}$ & $\begin{array}{c}\text { Standardised } \\
\text { Beta }\end{array}$ & $\mathbf{t}$ & Sig. \\
\hline Constant) & $\mathbf{0 . 0 6 1}$ & $\mathbf{0 . 1 1 7}$ & & $\mathbf{0 . 5 2 4}$ & .601 \\
\hline Maths & $\mathbf{0 . 4 6 1}$ & $\mathbf{0 . 0 7 8}$ & $\mathbf{0 . 4 3 1}$ & $\mathbf{5 . 9 4 3}$ & .000 \\
\hline Presentation & $\mathbf{0 . 4 3 1}$ & $\mathbf{0 . 0 7 6}$ & $\mathbf{0 . 3 9 8}$ & $\mathbf{5 . 6 6 4}$ & $\mathbf{. 0 0 0}$ \\
\hline Diagrams & $\mathbf{- 0 . 0 0 4}$ & $\mathbf{0 . 0 5 5}$ & $\mathbf{- 0 . 0 0 4}$ & $\mathbf{- 0 . 0 7 2}$ & .943 \\
\hline $\begin{array}{c}\text { Previous } \\
\text { knowledge }\end{array}$ & $\mathbf{0 . 0 9 4}$ & $\mathbf{0 . 0 5 4}$ & $\mathbf{0 . 0 9 4}$ & $\mathbf{1 . 7 4 2}$ & .084 \\
\hline
\end{tabular}

According to the results listed in Table 3, the following equation was obtained;

$\mathrm{TS}=0.061+0.461 \mathrm{MT}+0.431 \mathrm{PR}-0.004 \mathrm{DA}+0.094 \mathrm{PK}$

where,

TS $=$ tests scores

MT = mathematical approach

PR = presentation software, such as Power-Point

DA = drawing diagrams

PK = previous knowledge in taxation 
In this study, the mathematical and presentation approaches in learning externalities have positive relationships with tests scores, but drawing diagrams has the opposite relationship. Similarly, previous knowledge in taxation did not help the students to understand externalities better. Based on the regression results, mathematical and presentation approaches in different learning styles were deemed as significant variables that may have impacted the students' performances. Meanwhile, drawing diagrams and previous knowledge in taxation did not meet the necessary criteria to have any significant impact on the students' test scores.

The R-squared value showed that $62.4 \%$ of the scores obtained by the students can be explained by the application of mathematical tools and by using presentation software in the classroom. The remaining $37.6 \%$ can be explained by other variables that were not included in this study, such as learning environments. Out of the six topics surveyed (Introduction, Public Goods and Externalities, Social Insurance, Tax Analysis, Revenue System, and Central and Local Government Expenditure), $72.6 \%$ of the students cited externalities as the most interesting section of public finance.

\section{Learning Style Question 1:}

A video is showing air pollution in a city. The presenter is explaining the level of pollution using a graph shown on the screen. A text is also inserted for the viewers to read. I will learn more about this pollution by:

Reading the text.

Listening to the news by the presenter.

Watching the video.

Looking at the graph on the screen.

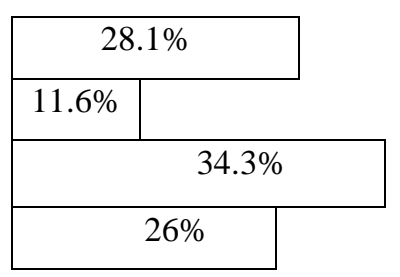

\section{Learning Style Question 2:}

I understand better when learning about net gains in well-being in internalising externalities using:

\begin{tabular}{|c|c|}
\hline Graphs $17.8 \%$ & \\
\hline $\mathrm{S}^{\prime}=\mathrm{MPC}+\mathrm{T}=\mathrm{N}$ & $\mathrm{SC} 3$ \\
\hline Group Discussion & $8.7 \%$ \\
\hline Textbook $19.2 \%$ & \\
\hline
\end{tabular}

\section{Conclusion}

The results of this study have shown that externalities can be understood in various ways. The traditional teaching method of using 'chalk and talk' should be complemented with modern technology or software to meet the current educational needs of the students. Watching videos while learning certain externality issues could help the students to experience real life situations. Mathematics is a core skill and it provides access to learning externalities in public finance. All these approaches may encourage more collaborative learning styles to enable students to grasp the concepts better. To quote Professor John D. Hey, we should let the students 'see and feel' the economics. 


\section{References}

Afzal, Muhammad Tanveer \& Fardous, Nazia (2016). Students' Preferences of Technology Usage for Their Learning Engagement. American Journal of Educational Research, 4(10), 749-751. doi: 10.12691/education-4-10-7

Arifin, Zainal (2015). Analyzing the Learning Styles of Junior High School Students and the Implication to English Teaching: A Case Study at SMPN 1 Dagangan Madiun. Jurnal Penelitian Humaniora, 16(1), 48-54. doi: 10.23917/humaniora. v16i1.1519

Bada, E., \& Okan, Z. (2000). Students' language learning preferences. TESL-EJ, 4(3).

Berenson, Mark L.; Levine, David M. \& Szabat, Kathryn A. (2015). Basic Business Statistics Concepts and Applications. Pearson Education Limited.

Carande-Kulis, Vilma G.; Getzen, Thomas E.\& Thacker, Stephen B. (2007). Public Goods and Externalities: A Research Agenda for Public Health Economics. Journal of Public Health Management and Practice, 13(2), 227-232.

Feldman, Enrique C. (2011). Living Like A Child: Learn, Live, and Teach Creatively. USA:Redleaf Press.

Hey, John (2003). Intermediate Economics. UK: McGraw-Hill Education.

Hey, John (2005). I Teach Economics, Not Algebra and Calculus. Journal of Economics Education, 36, 292-304.

https://www.uvic.ca/socialsciences/economics/index.php

https://www.khanacademy.org/economics-finance-domain/ap-microeconomics/ap-consumerproducer-surplus/ap-externalities-topic/v/negative-externalities

https://www.reuters.com/article/us-china-pollution/china-to-roll-out-nationwide-scheme-to make-polluters-repair-damage-pay-compensation-xinhua-idUSKBN1EC0BY

http://www.educationplanner.org/students/self-assessments/learning-styles-quiz.shtml https://www.stlouisfed.org/education/economic-lowdown-video-series/episode-5-externalities

Hudgins, D. (2010). Teaching synergistic integration of economics and mathematics. Journal of Economics and Economic Education Research, 11(1), 43-52.

Lari, F. S. (2014). The Impact of Using PowerPoint Presentations on Students' Learning and Motivation in Secondary Schools. Procedia - Social and Behavioral Sciences, 98, 1672 1677. doi: 10.1016/j.sbspro.2014.03.592

Misfeldt, M., Mariager-Anderson, K. \& Lindenskov, L. (2012). Does mathematics matter for learning economy? A survey of the state of the art. Proceedings of the 12 International Congress on Mathematics Instruction, Aalborg University.

Munich, D. \& Psacharopoulos, G. (2018 February). Education Externalities - What they are and what we know. European Expert Network on Economics of Education (EENEE) Analytical Report No. 34, prepared for the European Commission. doi: 10.2766/309796 Luxembourg: Publications Office of the European Union, 2018

Musgrave, R. A. \& Musgrave, P. B. (1984). Public Finance in theory and practice.International student edition, McGraw-Hill Education.

Pretty, Jules; Brett, Craig; Gee, David; Hine, Rachel; Mason, Chris; Morison, James; Rayment, Matthew; Gert Van Der Bijl \& Dobbs, Thomas (2010). Policy Challenges and

Priorities for Internalizing the Externalities of Modern Agriculture. Journal of Environmental Planning and Management, 44 (2), 263-283.

Sekaran, U. \& Bougie, R. (2013). Research Methods for Business: A skill building approach. UK: John Wiley \& Sons Ltd.

Semuels, A. (2019, June). The coming mountain of e-waste. TIME, 38-39.

Seung Mo Choi (2011, November). How Large Are Learning Externalities? International Economic Review, 52 (4), 1077-1103.

S. Rosen, H. \& Gayer, T. (2014). Public Finance. 10th ed., McGraw-Hill Education 
Smith, N. (2017, January 10). Sometimes It's Hard to Explain Market Failures. Bloomberg Opinion. Retrieved from https://www.bloomberg.com/opinion

The 8th IEEE International Conference on Advanced Learning Technologies, ICALT 2008, Santander, Cantabria, Spain, July 1-5, 2008. IEEE Computer Society 2008, ISBN 9780-7695-3167-0

Tisha L. N. Emerson \& Linda K. English (2016). Classroom experiments: Teaching specific topics or promoting the economic way of thinking? The Journal of Economic Education, 47 (4), 288-299.

University of Waterloo (2016, April 21). Need to remember something? Better draw it, study finds.

Retrieved

from

https://www.sciencedaily.com/releases/2016/04/160421133821.htm 